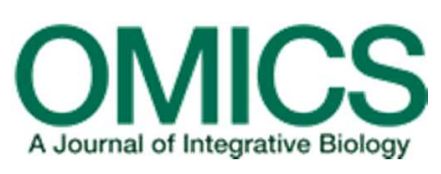

OMICS: A Journal of Integrative Biology: http://mc.manuscriptcentral.com/omics

\title{
PHARMACOGENETICS OF OSTEOPOROSIS: TOWARDS NOVEL THERANOSTICS FOR PERSONALIZED MEDICINE?
}

\begin{tabular}{|r|l|}
\hline Journal: & OMICS: A Journal of Integrative Biology \\
\hline Manuscript ID: & OMI-2011-0150.R4 \\
\hline Manuscript Type: & Reviews \\
\hline Date Submitted by the Author: & 24-Aug-2012 \\
\hline Complete List of Authors: & $\begin{array}{l}\text { Rojo, Karen; University Hospital Virgen de las Nieves, Pharmacogenetics } \\
\text { Unit- Pharmacy Service } \\
\text { Aguilera, Margarita; University Hospital Virgen de las Nieves, } \\
\text { Pharmacogenetics Unit- Pharmacy Service } \\
\text { García, Antonio; University Hospital Virgen de las Nieves, Rheumatology } \\
\text { Service } \\
\text { Cañada, Marisa; University Hospital Virgen de las Nieves, } \\
\text { Pharmacogenetics Unit- Pharmacy Service } \\
\text { Contreras-Ortega, Carlos; University Catolica del Norte, Chemistry } \\
\text { Calleja, Miguel; University Hospital Virgen de las Nieves, Pharmacogenetics } \\
\text { Unit- Pharmacy Service }\end{array}$ \\
\hline Keyword: & Genetic Variation, OMICS, Other, Genomic Technologies \\
\hline \multicolumn{2}{|c}{} \\
\hline
\end{tabular}




\section{PHARMACOGENETICS OF OSTEOPOROSIS: TOWARDS NOVEL} THERANOSTICS FOR PERSONALIZED MEDICINE?

Rojo-Venegas Karen*, Aguilera Margarita, Garre Marisa, García Antonio, ContrerasOrtega Carlos, Calleja Miguel Angel

*Corresponding author.

- Karen P. Rojo Venegas, Pharmacogenetics Unit - Pharmacy Service, Virgen de las Nieves University Hospital, Granada, Spain. Avenida de las Fuerzas Armadas 2, CP: 18014, Granada, Spain. Tel.34-958-020386. Fax 958-020004 Mail: krojo@correo.ugr.es - Margarita Aguilera Gómez. Pharmacogenetics Unit - Pharmacy Service, Virgen de las Nieves University Hospital, Avenida de las Fuerzas Armadas 2, CP: 18014, Granada, Spain. Pharmacy Faculty University of Granada, Campus Universitario de Cartuja, CP: 18071, Granada, Spain. Tel.34-958-020386. Fax 958-020004. Mail: maguiler@ugr.es

- Marisa Cañada Garre. Pharmacogenetics Unit - Pharmacy Service, Virgen de las Nieves University Hospital, Granada, Spain. Avenida de las Fuerzas Armadas 2, CP: 18014, Granada, Spain. Tel.34-958-020386. Fax 958-020004 Mail: marisacgarre@gmail.com

- Antonio García Sánchez, Rheumatology Service, Virgen de las Nieves University Hospital. Avenida de las Fuerzas Armadas 2, CP: 18014, Granada, Spain. Tel.34-958020625. Mail: angarcsan@gmail.com

- Carlos Contreras-Ortega, Department of Chemistry, Universidad Católica del Norte Antofagasta, Chile. Avenida Angamos 0610, Antofagasta, Chile. Tel. 56-55-355618. Mail: ccontrer@ucn.cl

- Miguel A. Calleja, Pharmacy Service, Virgen de las Nieves University Hospital, Avenida de las Fuerzas Armadas 2, CP: 18014, Granada, Spain. Tel.34-958-020386. Fax 958-020004. Mail: mangel.calleja.sspa@juntadeandalucia.es

Key words: Theranostics, novel diagnostics, antiresorptive drugs, clinical translation, BMD, fractures, polymorphisms, osteoporosis, pharmacogenetics. 


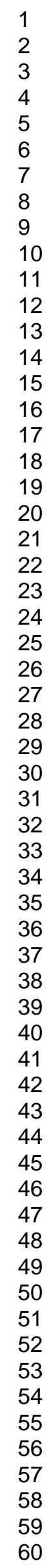




\begin{abstract}
Osteoporosis is a complex multi-factorial bone disorder with a strong genetic basis. It is the most common, severe, progressive skeletal illness that has been increasing particularly in developed countries. Osteoporosis will no doubt constitute a serious clinical burden in healthcare management in the coming decades. The genetics of osteoporosis should be analyzed from both the disease susceptibility and the pharmacogenetic treatment perspectives. The former has been widely studied and discussed, while the latter still requires much more information and research. This paper provides a synthesis of the literature on the genetics of osteoporosis and an update on progress made in pharmacogenetics of osteoporosis in recent years, specifically regarding the new molecular targets for antiresorptive drugs. In-depth translation of osteoporosis pharmacogenetics approaches to clinical practice demands a new vision grounded on the concept of "theranostics". That is, the integration of diagnostics for both disease susceptibility testing as well as for prediction of health intervention outcomes. In essence, theranostics signals a broadening in the scope of inquiry in diagnostics medicine. The upcoming wave of theranostics medicine also suggests more distributed forms of science and knowledge production, both by experts and end-users of scientific products. Both the diagnosis and personalized treatment of osteoporosis could conceivably benefit from the emerging postgenomics field of theranostics.
\end{abstract}




\section{INTRODUCTION}

Osteoporosis is a systemic skeletal disease characterized by low bone mass and deterioration in the microstructure of bone tissue, which causes bone fragility and the consequent increase in fracture risk (NIH Consensus Development Panel on Osteoporosis Prevention, Diagnosis, and Therapy, 2001). The disability resulting from osteoporosis in Europe is greater than the combined disability of all non-lung cancers (Lenise A., 2010). The lifetime fracture risk of a patient with osteoporosis is as high as $40 \%$, and fractures most commonly occur in the hip, spine or wrist (Rachner TD., 2011). Hip fracture (HF) is the most threatening because of its high mortality rate which can reach $30 \%$ the year after the fracture (Franzo A., 2005).

Osteoporosis is a multifactorial and polygenic disease (Ralston SH., 2002), so the individual likelihood of having a fracture depends on the combination of several risk factors, such as low bone mineral density (BMD) and genetic predisposition (Cummings SR., 1995; Rojo K., 2010).

The consequences of osteoporotic fractures generate significant direct and indirect economic impact on the level of healthcare needed. It is important to note that the impact of osteoporotic fractures on the economy has not been extensively studied and evaluated in hospitals. Estimations of the costs associated with hip fractures vary depending on the parameters analyzed. Hospital costs have demonstrated expenses that range from 9.000 (Pike C., 2010) to approximately 40,000 Euros (year/patient) (The Economic Cost of Hip Fracture in the UK, 2000). The studies do not take into account expenses such as hospitalization, ambulance, and primary care. Currently, these costeffectiveness analyses are starting to become increasingly important for global hospital management (Leslie WD., 2011; Blume SW., 2011). 
One of the best and most widely-used clinical determinants of the bone status of an individual is the BMD measurement (Kanis JA., 2002), which is considered a valid parameter for diagnosing osteoporosis and predicting fracture risk (Cummings SR., 2002). Although many external factors play fundamental roles in determining BMD, it has been estimated that over $50 \%$ of women and $70 \%$ of men who have suffered fractures did not previously have osteoporotic BMD values determined (Nguyen ND., 2007). Furthermore, in studies of osteoporosis therapy, increases in BMD were not linearly proportional to fracture risk reductions. The change in BMD induced by antiresorptive drugs explains approximately $15 \%$ of the reduction in fracture risk (Delmas PD., 2004). The International Osteoporosis Foundation projects that measure BMD using Dual-Energy X-ray Absorptiometry (DEXA) are believed to overestimate BMD by $20 \%$ to $50 \%$ (Johnell O., 2006) and are poor predictors of fracture in individuals. Advances in imaging techniques of factors such as cortical porosity with high-resolution peripheral CT may allow volumetric bone-density data to better predict bone strength, and thus fracture risk (Zebaze RM., 2010).

Decision-making methods such as the fracture-risk assessment tool (FRAX) have integrated clinical risk factors with DEXA-based BMD to predict an individual's 10 -year risk of sustaining a hip fracture, as well as the 10-year probability of having a major osteoporotic fracture, clinically-defined as spine, forearm, hip, or shoulder fracture. Each country adjusts this algorithmic tool to the data based on geographic variation Version 3.0 of the FRAX has shown to give lower probability estimates for major osteoporotic fracture and hip fracture than version 2.0, but has had little impact on rank order of risk. This tool bridges the gap between the parameters for diagnosing osteoporosis and identifying individuals with structurally compromised bone that causes an increased risk of fracture. However, as it is a recently-developed scale, it has 
limitations because it does not contain some important risk factors associated with falls and fractures. These risk factors may include high consumption of specific drugs like inhibitors of the proton pump, and benzodiazepines.

It is necessary to consider that discovering genes that affect osteoporosis comprise two main areas: genetics of disease susceptibility and pharmacogenetics of drug response. This review will approach pharmacogenetics of drug response and its implications to current clinical practice including a review of the validation process, which allows the development of specific guidelines. Future perspectives of pharmacogenetic research should be supported by validation processes, which would involve the control of different parameters related to accuracy, precision, and repeatability of the genotyping methods. We will first give a brief overview of the genetics of osteoporosis, and then proceed to studies in pharmacogenetics of osteoporosis.

\section{GENETICS OF OSTEOPOROSIS}

The genetics of osteoporosis has revealed promising associations between many polymorphisms in candidate genes and bone traits, both quantitative and qualitative. The association of many candidate genes with BMD and osteoporotic fracture risk has become controversial, owing to the failure of independent replication, possibly due to insufficient statistical power and false-positive results. Genes involved in common bone formation/destruction pathways have been described as being related to the risk of osteoporosis, the risk of hip and vertebral fractures, and to BMD values. Therefore, these gene variants could affect homeostasis and bone structure, and as a result, BMD values. 
Given the available studies from different reviews and the clinical importance of osteoporosis, this section will focus on those pathways and genes most frequently studied in relation to BMD and osteoporosis fracture risk.

In this context, one of the active pathways is the osteoclastogenesis pathway, which is related to the process of bone remodeling through the activity of $O P G, R A N K$ and $R A N K-L$ loci (Hofbauer LC., 2000). RANK and $R A N K-L$ play a significant role in the signaling enhancement pathway of the number, survival and activity of osteoclast. $O P G$ acts as a competitor of $R A N K$ in binding to the $R A N K-L$ receptor, thus inhibiting the activity of osteoclasts (Jones HD., 2002; Pearce SH., 1997).

The Wnt signaling pathway participates in the process of bone formation and resorption by including transmembrane proteins such as LRP5, LRP6 (Tamai K., 2000) and ITGB3. The Wnt signaling pathway is essential for the maturation of osteoclasts, and thus for bone resorption (Teitelbaum SL., 2000).

Likewise, the active metabolite of vitamin $\mathrm{D}(1 \alpha, 25(\mathrm{OH}) 2 \mathrm{D} 3)$ plays a fundamental role in bone metabolism by binding to its $V D R$ receptor. $V D R$ regulates calcium homeostasis through the binding and nuclear translocation of the $1 \alpha, 25[\mathrm{OH}] 2 \mathrm{D} 3$, in order to regulate bone turnover and increase gut calcium absorption (Wesley P., 2002).

Synthesis of estrogens is essential for the acquisition and maintenance of bone mass, predominantly in women (Ichikawa S., 2005). The physiological functions of estrogens are performed when they bind to the $\alpha^{-}$and $\beta$-receptors $(E S R-\alpha, E S R-\beta)$, the final biological impact being expressed in both osteoblasts and osteoclasts (Bord S., 2001).

Moreover, collagen is an important component of the body's structural proteins. COL1A1 is the largest and most abundant constituent of all bone tissue proteins, and 
mutations in its structure or regulation are associated with osteoporosis (Byers PH., 1990).

In homeostasis, the calcium-phosphorus pathway is the Calcium Sensing Receptor (CaSR), which belongs to the G-protein coupled receptor super family, and serves as a sensor of the extracellular calcium levels in different tissues (Pearce SH., 1997). It is expressed in bone cells, and recent data indicate that this receptor can be involved in the regulation of osteoclastic bone resorption (Kameda T., 1998).

The key enzymes in the mevalonate pathway are FDPS and GGPS1. These enzymes are targets in the isoprenoid biosynthesis. This pathway has been demonstrated to be involved in the regulation of mechanisms by which bisphosphonates induce apoptosis of osteoclasts (Marini F., 2008; Choi HJ., 2010).

The genetic analysis in osteoporosis includes the use of high throughput whole genome expression microarray applications (a technology that allows researchers to study the expression of many genes at once). This technology has found specific upregulated or down-regulated genes, and has discovered putative clinical biomarkers. This analysis describes the functional studies of expression, but the results are controversial. The results of osteoporosis-related genes based on microarray identification have been obtained at the cellular level in primary cultures of human osteoblasts (Trost Z., 2010).

A compilation of the main genetic factors described through potential candidate gene, genome-wide association studies (GWAS) and meta-analyses related (Hsu Y., 2010; Richards JB., 2009; Rivadeneira F., 2009; Styrkarsdottir U., 2009; Ralston SH., 2010; 31:629-62; Ralston SH., 2010; 1192:181-9; Mencej-Bedrac S., 2009; Reppe S., 2010; Uitterlinden AG., 2006; Ji GR., 2010; Fang Y., 2006; Macdonald H., 2006; Mann V., 2003; Yazdanpanah N., 2007; Kapur K., 2010; Tsukamoto K., 2000; Harding B., 
2006; Levy ME., 2007) with osteoporosis, BMD and osteoporotic fractures are summarized in Table 1, which identifies the main genes with their respective signalling pathways, and genetic or genomic screening technologies and/or approaches.

The conflicting results compiled for each pathway are possibly owing to the complexity of the osteoporosis phenotype itself, added to the limitations in the molecular tools available. These conflicts should be approached by using improved screening, risk assessment, diagnosis and treatment initiation (MacLaughlin E., 2010). In this regard, an important contribution would be the complementary use of validated pharmacogenetic tests in clinical practice (Lamberts S., 2009; Van Straaten T., 2010).

\section{PHARMACOGENETICS OF OSTEOPOROSIS}

\section{Osteoporosis Pharmacotherapy:}

The therapeutic breakthroughs that have emerged for the treatment of osteoporosis may improve bone quality (the constellation of bone architecture, bone turnover, and damage accumulation and mineralization) and bone quantity (integration of bone mass, estimated by BMD). These breakthroughs are within a range of pharmacological alternatives, which are used for prevention of osteoporotic fractures (Delmas PD., 2005).

The treatments used in this disease fall into two classes: antiresorptive drugs and anabolic drugs (Gates BJ., 2009). Antiresorptive drugs, such as bisphosphonates (BP) (alendronate, risedronate, etidronate, ibandronate, zoledronate), raloxifene, and estrogen, slow down bone resorption. Anabolic drugs stimulate bone formation, and include teriparatide (parathyroid hormone) and possibly strontium ranelate which has been suggested to induce a combination of modest effects on bone formation and resorption. Widely accepted clinical guidelines have concluded that all these drugs have 
been shown to reduce the risk of osteoporotic fractures to a greater or lesser extent, along with concomitant increases in bone density and decreases in high bone turnover. Due to advances in genomic and proteomic studies which revolutionized drug discovery and validation processes, new prospects have emerged for the identification of novel therapeutics against skeletal diseases (Rachner TD., 2011). According to new pharmacology treatment, there are drugs that have been developed based on monoclonal antibody actions and small molecules mimicking similar designs established for anticancer molecular-directed therapy: Denosumab, Odanacatib, Saracatinib, and antibodies against the proteins sclerostin and dickkopf-1 (two endogenous inhibitors of bone formation) (Rachner TD., 2011; Lewiecki EM., 2011). Of these molecular drugs, only Denosumab has been approved by the FDA and EMEA for osteoporosis treatment.

\section{Pharmacogenetics of Osteoporosis Treatment}

The great majority of association studies have investigated only those genes which affect BMD, bone turnover marker variation, and fracture risk; they could be independent from genes affecting drug responses (adverse affect and efficacy limitations).

The field of pharmacogenetics, which represents the use of individual genetic data to predict the outcome of a drug treatment in relation to efficacy and adverse effects, could be a valuable avenue of study (Gervasini G., 2010)

The variability in osteoporosis drug response is much more complicated than simple variability in BMD, bone turnover markers or fracture risk becauseit is necessary to consider other intrinsic characteristics of the patient (morbidity, enviromental factors) that impact the kinetics and dynamics of the drug, and therefore the end-of-treatment response. Thus, it will be very important in future work to define the phenotypes of 
osteoporosis drug response (disease, quality of life, food, drugs) and to enlarge pharmacogenetic studies to include genes involved in drug-specific pharmacokinetics and pharmacodynamics.

Due to the controversial results of the studies of expression and to potential concern to clinicians and patients in non-responders to osteoporosis therapy (Lewiecki EM., 2003) the emerging field of pharmacogenetics is very useful for refining and optimizing osteoporosis drug treatment. Pharmacogenetics could potentially allow the identification of the most effective drug and dose for each patient in terms of beneficial and adverse effects, based on the single genotype expression. In order to develop this area, the study of pharmacogenetics of osteoporosis should include the understanding of molecular mechanisms of drug action, the identification of drug response candidate genes and their variants, and the expansion towards clinical trials that include patients' genetic profiles. These approaches could provide useful tools to tailor decisions about osteoporosis drug treatments in order to maximize the health and well-being of osteoporotic patients.

To date, no more than 20 studies of the pharmacogenetics of osteoporosis have been published. The great majority of these studies have demonstrated modest effects in response to anti-resorptive drugs. Primarily, major osteoporosis candidate genes, such as those encoding the VDR (Palomba S., 2003; Marc J.,1999; Palomba S., 2005) ER$\alpha / E R-\beta$ (Heilberg IP., 2005; Arko B., 2002) and COL1A1 (Qureshi AM., 2002), have demonstrated a different effect on lumbar BMD and hip BMD depending on the genotype of the patients. Some interesting studies observed that in the VDR polymorphism (BsmI genotype: $\mathrm{BB}, \mathrm{Bb}, \mathrm{bb}$ ) the major effectiveness (increase on $\mathrm{DMO}$ ) was in patients' homozygous BB when they were treated by Raloxifene (Wang C., 2009) or Etidronato (Creatsa M., 2011) alone. In other cases (Rizzoli R., 2011), in 
heterozygous $\mathrm{Bb}$ and homozygous $\mathrm{BB}$ patients, the combination of Alendronato (ALN) with Hormone Replacement Therapy (HRT) and the association of Raloxifene plus ALN had a stronger effect on BMD compared with either HRT or Raloxifene treatment alone, but no more effective than ALN alone. In the cases of $E R$ gene polymorphisms, it was observed that patients' homozygous PP for the PvuII polymorphism (genotype: PP, $\mathrm{Pp}, \mathrm{pp}$ ) and patients' homozygous $\mathrm{xx}$ for the $\mathrm{XbaI}$ polymorphism (genotype: $\mathrm{XX}, \mathrm{Xx}$, xx) exhibited better lumbar spine BMD response values when treated with antiresorptive Raloxifene (Siris ES., 2009). Patients with genotype Rr for the RsaI SNP (genotype: RR, Rr, rr) showed a smaller increase in BMD, but did not show a significant responsive to ALN therapy. For COL1A1 gene polymorphism (Sp1 genotype: SS, Ss, ss), it was shown that site-specific heterogeneity exists in the response of BMD to cyclical Etidronate therapy (Kennel KA., 2009). In patients' homozygous SS, the response of femoral neck BMD increased significantly in comparison to the rest of the genotype.

As noted in the studies above, research in pharmacogenetics of osteoporosis has been conducted mainly with antiresorptive drugs. This may be because important clinical guidelines have recommended the use of these drugs for primary and secondary prevention of osteoporosis and osteoporotic fractures. As described in the analyzed studies, the effect of antiresorptive drugs will depend primarily on the genotype expressed in the patient. It is possible that the difference in the response of each drug in relation to genetic polymorphisms is related to the mechanism of action.

\section{Recent studies on Pharmacogenetics of antiresorptives:}

In order to update the studies in pharmacogenetics of antirresorptive drugs, this section will analyze in detail the studies performed in the last four years regarding the 
response of these drugs depending on the genotypic characteristics of the patients. Table 2 summarizes the studies based on pharmacogenetics of antiresorptives.

Six novel studies specifically related to pharmacogenetic osteoporosis treatment response merit special consideration. One of these studies, (2008), evaluated the effects of the rs $1800012(\mathrm{G}>\mathrm{T}) \mathrm{SNP}$ of the COL1A1 gene on BMD response to at least 3 years of low-dose hormone replacement therapy in 111 postmenopausal Turkish women (Simsek M., 2008) and demonstrated that the increase in lumbar BMD and femoral BMD were higher in women with the homozygous GG genotype compared to those with the heterozygous genotype.

In the same year, a study of 234 osteoporotic Danish women associated the rs2297480 (A>C) SNP of FDPS, the molecular target of amino-bisphosphonates in osteoclasts, with the response to 2-year amino bisphosphonate treatment (Ralston SH., 2010). They found that subjects with the homozygous CC genotype showed a decreased response by urinary Crosslaps after two years, but not after one year of aminobisphosphonate therapy (Alendronate or Ibandronate) when compared to the heterozygous $\mathrm{AC}$ and to the homozygous $\mathrm{AA}$ genotypes. However, FDPS polymorphism did not show any relationship to baseline spinal and femoral BMD.

In 2009, a study analyzed the influence of the rs3736228 (C>T) and rs4988321 (G>A) polymorphisms of the LRP5 gene in a cohort of 249 osteoporotic or osteopenic men (Kruk M., 2009). The results showed that the rs3736228 (C>T) polymorphism was associated with hip BMD in osteoporotic men before treatment. However, there was no association between these polymorphisms and BMD and bone turnover response after 2 years with risedronate treatment.

In the same year, 80 postmenopausal women were studied to determine if the A163G (genotype: AA, AG, GG) and T245G (genotype: TT, GT, GG) polymorphisms 
of the OPG gene are associated with the change of hip BMD and lumbar spine BMD after alendronate therapy (Wang C., 2009). This study observed that after 12 months of treatment, the percentage of BMD change at the femoral neck was higher in genotype AA, while at site $\mathrm{T} 245 \mathrm{G}$, the percentage of BMD change at inter-troche and total hip were higher in genotype TT, concluding that both genotypes show a better therapeutic effect to alendronate.

In 2010, a study of 144 osteoporotic Korean women (Mencej-Bedrac S., 2009), investigated whether genetic polymorphisms of FDPS (rs2297480 and rs11264361) or GGPS (the rs3840452 and rs3841735) genes were associated with the response to alendronate or risedronate in terms of changes in lumbar spine and femoral neck BMD. After 1 year of treatment, it was found that women with two deleted alleles of GGPS1 8188A ins/del (rs3840452) had significantly higher femoral neck BMD at the baseline compared with those with one or no deleted alleles. The response rate of women with two deleted alleles of GGPS1 -8188A ins/del was significantly lower than the rate of women with one or no deleted alleles. Moreover, women with two deleted alleles of GGPS1 -8188A ins/del had a 7-fold increased risk of non-response to bisphosphonate therapy compared to women with other genotypes in GGPS1 -8188, after adjusting for baseline BMD. No polymorphisms of the FDPS gene were associated with lumbar spine BMD or femoral neck BMD.

A recent pharmacogenetics of osteoporosis study evaluated the effect of the BsmI (G>A) polymorphism of the VDR gene in forty-two postmenopausal women receiving alendronate or teriparatide during 1 year (Creatsa M., 2011). The results showed the effectiveness on BMD only with alendronate treatment. Carrier patients of the $\mathrm{b}(\mathrm{A})$ allele $(\mathrm{Bb} / \mathrm{AG}, \mathrm{bb} / \mathrm{AA})$ were more responsive to treatment compared to patients with the BB (GG) genotype BsmI polymorphism. 
Global results from these studies suggest that patient genotyping could be useful to target subjects most likely to respond to osteoporosis drug treatments in terms of BMD and bone turnover marker changes. However, association studies can have some limitations, such as inadequate sample size or sampling errors, genetic differences between ethnic groups, the presence of gene-gene and/or gene-environment interactions acting as confounding factors, the complexity of genome and gene regulation (epigenetic factors, somatic mutations, microRNAs), frequent accidental statistical association (not due to a real association between genotype and phenotype), and the lack of independently replicated studies. For all these reasons, no definite gene variations have conclusively been shown to be responsible for the regulation of any antiosteoporosis drug responses. This research has contributed to the understanding of this disease and has demonstrated the influence of genetic polymorphisms in response to antiresorptive treatment. For a proper and efficient application to clinical practice, it is essential to consider the key issues that will be discussed below.

\section{Adverse drug reactions associated with genetic factors}

Drugs do not always reach their therapeutic target because they are not equally effective in all patients, and may lead to a variety of adverse effects.

Although osteoporosis drugs are effective in the majority of cases, most are associated with adverse effects (Rizzoli R., 2011) that render long-term administration and adherence problematic (Siris ES., 2009). Several genes have been evaluated that could be related to these adverse effects. Table 3 shows the main side effects of treatments for osteoporosis (antiresorptive and anabolic drugs).

Table 3 shows adverse effects of antiresorptive treatment, particularly bisphosphonates (esophageal irritation, thromboembolic disease). The most threatening 
side effect of bisphosphonates is the development of osteonecrosis of the jaw (ONJ), which is the only side effect associated with genetic factors (Kennel KA., 2009). The incidence of ONJ in patients treated for osteoporosis is low $(0.1 \%)$ while the incidence in cancer patients treated with high doses of intravenous drugs is higher (3-10\%) (Reid IR., 2009; Franken AA., 2001). During the last 4 years, 6 genes have been proposed to be involved in the risk of developing ONJ (Sarasquete ME., 2008; Sarasquete ME., 2009; Lehrer S., 2009; Katz J., 2011; Marini F., 2011) and the most relevant of these studies are summarized in Table 4.

One GWAS_determined the role of genes in the pathogenesis of ONJ after 2 years of intravenous BP treatment (pamidronate or zaledronate), carried out in 2 groups of patients with multiple myeloma (22 with ONJ and 65 without) (Pietschmann P., 2009). Homozygosis for the $\mathrm{T}$ allele of the $C Y P 2 C 8 \mathrm{rs} 1934951$ (C>T) was associated with an increased risk of developing ONJ. Among genetic factors, $C Y P 2 C 8$ polymorphisms are arising as a promising risk factor, and the bisphosphonate-related ONJ can be predicted by an association of genetic and environmental risk factors (Pietschmann P., 2009; Patsch JM., 2011). However, this conclusion has not been confirmed by studies on an independent series of patients, so it remains to be seen if that association is a consequence of the genetic background and/or environmental factors unique to the population studied. Despite the interesting contribution of this preliminary study through a GWAS, variability in the genes encoding $C Y P 2 C 8$ would not play a role in the metabolism of $\mathrm{B}$, because these drugs do not undergo any physical-chemical modification (Gong L., 2011).

Another study (Haney E., 2008) proposed the matrix metalloproteinase 2 $(M M P 2)$ protein as the candidate gene for bisphosphonate-induced ONJ. The study determined whether any abnormalities in serum bone markers are related to 
bisphosphonate-induced ONJ in patients ( 2 metastatic breast cancer, 3 osteoporosis, 1 prostate cancer, and 1 Gaucher`s disease) treated with intravenous or oral BPs (pamidronate, zoledronate or alendronate). This protein was selected on the basis of its potential involvement in the breakdown of extracellular matrix in normal physiological processes, such as embryonic development, reproduction, and tissue remodelling, as well as in disease processes, such as arthritis and metastasis. Although the values of bone turnover markers in these patients were normal, the study proposed that $M M P 2$ is a candidate gene for bisphosphonate-induced ONJ for 3 reasons: 1) MMP2 is associated with bone abnormalities which could be related to ONJ, 2) $M M P 2$ is the only gene known to be associated with bone abnormalities and atrial fibrillation, and 3) a network of disorders and diseases, genetically linked by known disorder-gene associations, indicates that cardiovascular diseases and bone diseases are related. This suggests that a single drug such as a bisphosphonate, acting on a single gene, $M M P 2$, could have both bone and cardiovascular side effects different from the osteoclast inhibition that is characteristic of bisphosphonates. Nevertheless, further studies on patients without ONJ are needed.

A third study (Dagdelen S., 2007) explored the possible genetic variability of seven genes associated with drugs, risk of osteoporosis and bone metabolisms $(C Y P 2 C 8, C O L 1 A 1, R A N K, O P N, M M P 2, O P G$ and $T N F)$ as the predictive risk factor for the development of bisphosphonate-induced ONJ. This study was performed on a cohort of 78 patients with multiple myeloma (12 with ONJ) who received intravenous BP (pamidronate or zaledronate) over 1 year. The results indicated that the risk of developing $\mathrm{ONJ}$ is 4 times higher in patients with a history of smoking than those without a history of smoking $(\mathrm{p}=0.048)$. The authors also found that the type of BP treatment associated with ONJ in patients treated with pamidronate, resulted in patients 
having 4 times higher risks of developing bisphosphonate induced-ONJ compared with those on zaledronate. Moreover, it was observed that the carriers of individual SNPs for COL1A1 (rs1800012), RANK (rs12458117), MMP2 (rs243865), OPG (rs2073618) and $O P N$ (rs11730582) had a trend towards higher odds ratio for developing ONJ in multiple myeloma patients undergoing intravenous BP therapy. The probability of this trend increased 11-fold for the combined genotype score of the five SNPs listed above.

Finally, a recent study (Mani A., 2007) makes an interesting analysis of the influence of rs2297480 (A/C) SNP on the target FDPS gene (an enzyme involved in the mechanism of action of the BP), in a cohort of 68 Caucasian patients with multiple myeloma, metastatic mammary and prostate cancer treated with an intravenous BP (zoledronic acid). The results of this case-controlled study demonstrated significant differences in the AA and CC genotype frequencies of this SNP between ONJ cases, and controls with a positive correlation between AA carrier status and disease expression $(\mathrm{p}=0.033)$. It also showed differences between CC carrier status and the absence of the ONJ complications after 18-24 months of intravenous zaledronic acid treatment $(\mathrm{p}=0.045)$. These results are in agreement with the study previously described (Ralston SH., 2010) in which higher responsiveness of the AC and AA genotypes to oral treatment with amino-BP was found when compared to CC genotype. It could be assumed that the A allele segregates with the ONJ complications through a positive modulation of the response to a potent amino-BP, like zoledronic acid. However, the authors determined no direct causative relationship between ONJ and FDPS gene polymorphisms. They propose to confirm this study in other patient cohorts as well as the validation of this genetic marker for ONJ.

Therefore, it remains to be determined whether the BPs are the cause of ONJ development. The possibility of environmental and/or genetic variation between 
individuals may confer susceptibility or resistance to developing ONJ. No pharmacogenetic studies related to other side effects have been reported at this time.

\section{Other factors associated with osteoporosis treatment response.}

Many risk factors contribute to the pathogenesis of osteoporosis. Aging affects bone density variations that are also mainly determined by genetic factors. Nevertheless, not only genetic factors have an observable effect. In addition, lifestyle factors such as weight-bearing physical activity; nutrition (insufficient calcium and vitamin D intake, excessive alcohol consumption); nicotine abuse; illnesses that affect the bone (kidney failure, hypothyroidism); or the intake of medications with a negative impact on bone metabolism (such as diuretics or inhibitors of the proton pump) are risk factors for osteoporosis and can affect drug responses (Weinshilboum R., 2003).

Genetic variations in a population create an impressive spectrum of phenotypic diversity, particularly when changes in diet or environment are superimposed on the population. GWAS have become powerful tools for linking sequence variants with overlying systems level phenotypes, but they do not provide insight into the mechanisms through which genetic variation drives phenotypic variation (Voy BH., 2011). Systems genetics is an emerging discipline that provides a means to fill this knowledge gap by assembling a hierarchy of interactions among genes, proteins, and other intermediate phenotypes that manifest themselves as phenotypic variations.

On the other hand, no conclusive results have determined whether there is a difference in the response to the treatments used for osteoporosis, taking into account age, gender, and environmental factors (disease, calcium intake, exercises, among others) or if none of these factors are associated with or influenced by genetics. However, it is necessary to consider some aspects that will be described below. 
Osteoporosis is an age-related disease with several gender-specific differences, more prevalent in women than men; however, once a hip fracture has occurred, mortality is higher in men (Rojo K., 2010). Differences in sex hormone production, especially the abrupt decline of estrogens in women, are responsible for inter-gender differences in the pathophysiology of osteoporosis.

The treatment of osteoporosis also differs by gender; therapy options have been studied only in women (Pietschmann P., 2009). Men have no pharmacological protection from the disease (Patsch JM., 2011). Therefore, the treatment in men is understudied and the magnitude of the impact of male osteoporosis has been also underestimated (Haney E., 2008).

Another important aspect in the response to the treatment of osteoporosis is that some studies have shown the influence of certain diseases. In a retrospective, matched case-control study, the efficacy of alendronate in postmenopausal osteoporotic women with type 2 diabetes mellitus (DM) was evaluated by the change in BMD. Patients with type 2 DM proved resistant to long-term BP treatment, especially in hip, femoral neck, and forearm regions of t BMD (Dagdelen S., 2007). Metabolic syndrome diseases such as DM are genetically linked to a missense mutation in LRP6 (Wnt signaling), one of the genes related to osteoporosis (Mani A., 2007).

It is well analyzed that Vitamin D deficiency has been related to osteoporosis. Patients with low BMD and an initial deficiency of Vitamin D were tested with alondronate and raloxifene, and their response showed that basal status does not affect BMD response to BPs when they were co-administered with Vitamin D and calcium (Antoniucci DM., 2009; Antoniucci DM., 2005). On the contrary, a study performed in women with postmenopausal osteoporosis showed that optimal vitamin D status seems to be necessary in order to maximize the response to antiresorptives (alendronate, 
risedronate and raloxifene) in terms of both BMD changes and anti-fracture efficacy (Adami S., 2009).

In addition, a decrease in calcium absorption could contribute to the pathogenesis of osteoporosis. A recently randomized, double-blind, placebo-controlled and multicenter clinical trial (Shapses SA., 2001) evaluated whether alendronate increased the fractional calcium absorption (FCA) in postmenopausal women with low BMD and Vitamin $\mathrm{D} \leq 25 \mathrm{ng} / \mathrm{ml}$. Patients who were treated during 5 weekly doses of alendronate $70 \mathrm{mg}+$ Vitamin $\mathrm{D}(3) 2800 \mathrm{IU}(\mathrm{ALN}+\mathrm{D})$ showed an increase in FCA compared with those who received the placebo.

In general, external factors such as age and gender, as well as modifiable factors such as intake of calcium and vitamin D, not only have implications as risk factors for osteoporosis, but probably in response to treatment.

\section{Translation of pharmacogenetic findings to clinical practice}

The translation_of pharmacogenetic findings of osteoporosis-related bone fractures to clinical practice should be addressed in both a general context, and with parallel advancements in other pharmacogenetic treatment approaches.

In order to accelerate the translation and transition based on scientific results found in screening drug effects over a different inter-individual patient population, the following recommendations are proposed.

\section{Additional Research}

1) Analytical performance characteristics of biomarkers, stratification, identification of responders, or tests to avoid prescribing to either biomarker positive or biomarker negative subjects should be established (Tesch G., 2010). 2) All 
polymorphisms in genes that can directly or indirectly affect these markers should be studied for their potential as putative genomic biomarkers. However, there is no evidence of clinical use of multiple pharmacogenetic variable genes, due to the controversial result of association which has been described throughout this review. It is well known that classical therapeutic approaches in osteoporosis have been established for controlling marker turnover, bone formation, and bone resorption that are now commercially available for decreasing fracture rate as the clinical end-point. 3) Global analysis of variability in bone gene pathway profiles of patients could help solve the contradictory findings from gene-isolated SNP studies (Karasik D., 2012). 4) The use of a putative biomarker in several populations (Zhang LS., 2011) should be verified and replicated by performing similar pharmacogenetic studies on the general population to contribute data to serve as validation. The validation process would involve the control of different parameters related with accuracy, precision, and repeatability of the genotyping methods. These important steps could become a reality through the use of high throughput technologies. 5) Create an international consortium which evaluates the results of studies retrieved from various clinical and research teams done on different populations by genotyping candidate genes and GWAS data. To date, 20 genome-wide association studies (GWASs) for osteoporosis and related traits have been conducted, identifying dozens of genes (Zheng HF., 2011).

Government and External Regulation

6) Genetic findings must be supervised and approved by the appropriate public entity. They should allow the implementation of specific and reliable tests for those valid biomarkers that have demonstrated association with the safety and efficacy of therapy. 7) The provision of specific recommendations and guidelines from an expert consortium 
on pharmacogenetics (Becquemont LM., 2011) would quickly help to introduce biomarkers in clinical practice. 8) Expert government expert agencies must be responsible for regulating and determining the status of a specific biomarker and also the initiatives pursued until their mandatory use in hospitals or clinics. There are consortiums of experts such as Joint Voluntary Genomic Data and Submission (VGDS) from the FDA/EMA that process this type of information (U.S. Food and Drug Administration). 9) Guidelines of anti-osteoporosis drugs necessary for pharmaceutical care should be elaborated (Drieling RL., 2011). These guidelines could also include recommendations of specific pharmacogenetic testing (Dell R., 2010).

\section{Clinical Application}

10) Important investments and coordinated macro studies will be necessary to improve the quality of life of the elderly patient population, because fractures related to osteoporosis will continue to be a substantial and growing public health problem. 11) An algorithm including a flow-chart of decision-making priorities for demonstrated genotypes should be developed, that could impact bone patient status, even if this task was considered highly difficult and controversial It could help to establish the basis for future application. 12) Clinical evidence of the effectiveness of very recently-reported molecules should be provided, which could lead to better practice of pharmacotherapy because no specific guidelines have been designed for them (National Institute for Health and Clinical Excellence (NICE): Technology appraisal guidance 160, 2010; National Institute for Health and Clinical Excellence (NICE): Technology appraisal guidance 161, 2010). In that regard, the weakness of the pharmacogenetics of osteoporosis and its pharmacological treatments is that therapeutic decisions are not harmonized due to the complexity and heterogeneous manifestation of the disease. 
Other important considerations must be taken into account before the translation of pharmacogenetic achievements can be used in routine clinical practice, such as molecular biology pharmacogenetic formation, ethical-legal issues, quality management in genetic test laboratories, ISO norms, and cost-effective successful strategies.

Clinicians must be properly informed for the administration of and application of the requirements for genetic tests. Moreover they must have the proper infrastructure required for analysing the sample and interpretation of results, and coordinating themselves. Thus, training at the undergraduate and graduate level must be enhanced.

Currently, specific formation programs for pharmacogenetics are scarce and limited to a select number of schools of pharmacy and medicine (Murphy JE., 2010; Maize DF., 2010). Moreover, a general lack of knowledge of molecular genetics constitutes the first barrier to implement pharmacogenetic tests in routine clinical practice. Previous experiences described in pharmacogenetic literature can help to establish models for effective advancement in pharmacogenetic applications (Gurwitz D., 2010).

Further limitations to the translation of validated pharmacogenetic biomarkers and biomarkers under research in clinical applications include cost-effectiveness, economic incentives, reimbursement issues, and the difficulty of making real evaluations of these limitations. Today, there are few studies evaluating the economic aspect of osteoporosis management that could decrease the hip fracture rate by $25-50 \%$ and be cost-effective at the same time (Dell R., 2010). Thus, to overcome the first step of implementation of pharmacogenetics as a useful tool in a hospital context, more osteoporosis therapy studies must be conducted. 


\section{Future perspectives}

This paper provided a synthesis of the literature on the genetics of osteoporosis and an update on progress made in pharmacogenetics of osteoporosis in recent years, specifically regarding the new molecular targets for antiresorptive drugs. In-depth translation of osteoporosis pharmacogenetics approaches to clinical practice demands a new vision grounded on the concept of "theranostics". That is, the integration of diagnostics for both disease susceptibility testing as well as for prediction of health intervention outcomes. The exponential progress and technological advances since the elucidation of the human genome provide opportunities for gaining a better understanding of complex diseases, including osteoporosis as seen through the lens of theranostics. The success in finding osteoporosis genes rests on the collection of large number of cohorts of clinically well-characterized individuals. It is expected that with such statistically robust large-scale studies, many of the genes that contribute to interindividual variation in therapeutic responses influenced by osteoporosis phenotypes will likely be identified. Ultimately, theranostics of osteoporosis is an essential emerging approach to diagnostic medicine whereby the genomics components of both the disease and its treatment are considered inseparable, and thus requiring an integrative vision in both disease biology and clinical therapeutics.

\section{Acknowledgment:}

The authors thank Irene Fotinos and Meredith Moore for assisting us with the editing process. 


\section{References}

ADAMI S., GIANNINI S., BIANCHI G., SINIGAGLIA L., DI MUNNO O., FIORE CE., et al. (2009). Vitamin D status and response to treatment in post-menopausal osteoporosis. Osteoporos Int. 20, 239-44.

ANTONIUCCI DM., VITTINGHOFF E., PALERMO L., BLACK DM., SELLMEYER DE. (2009). Vitamin D insufficiency does not affect response of bone mineral density to alendronate. Osteoporos Int. 20, 1259-66.

ANTONIUCCI DM., VITTINGHOFF E., BLACKWELL T., BLACK DM., SELLMEYER DE. (2005). Vitamin D insufficiency does not affect bone mineral density response to raloxifene. J Clin Endocrinol Metab. 90, 4566-72.

ARKO B., PREZELJ J., KOMEL R., KOCIJANCIC A., MARC J. (2002). No major effect of estrogen receptor beta gene RsaI polymorphism on bone mineral density and response to alendronate therapy in postmenopausal osteoporosis. J Steroid Biochem Mol Biol-81,147-52.

BECQUEMONT L., ALFIREVIC A., AMSTUTZ U., BRAUCH H., JACQZAIGRAIN E., LAURENT-PUIG P., et al. (2011). Practical recommendations for pharmacogenomics-based prescription: 2010 ESF-UB Conference on Pharmacogenetics and Pharmacogenomics. Pharmacogenomics. 12, 113-24.

BLUME SW., CURTIS JR. (2011). Medical costs of osteoporosis in the elderly Medicare population. Osteoporos Int. 22, 1835-44.

BORD S., HORNER A., BEAVAN S., COMPSTON J. (2001). Estrogen receptors $\alpha$ and $\beta$ are differentially expressed in developing human bone. J. Clin. Endocrinol. Metab. 86, 2309-2314.

BYERS PH. (1990). Brittle bones fragile molecules: disorders of collagen gene structure and expression. Trends Genet. 6, 293-300.

CHOI HJ., CHOI JY., CHO SW., KANG D., HAN KO., KIM SW, et al. (2010). Genetic polymorphism of geranylgeranyl diphosphate synthase (GGSP1) predicts bone density response to bisphosphonate therapy in Korean women. Yonsei Med J. 51, 2318 .

CREATSA M., PLIATSIKA P., KAPAROS G., ANTONIOU A., ARMENI E., TSAKONAS E., et al. (2011). The effect of vitamin D receptor BsmI genotype on the response to osteoporosis treatment in postmenopausal women: a pilot study. J Obstet Gynaecol Res. 37, 1415-22.

CUMMINGS SR., BATES D., BLACK DM. (2002). Clinical use of bone densitometry: scientific review. JAMA. 288, 1889-97.

CUMMINGS SR., NEVITT MC., BROWNER WS., STONE K., FOX KM., ENSRUD KE., et al. (1995). Risk factors for hip fracture in white women. Study of Osteoporotic Fractures Research Group. N Engl J Med. 332, 767-73. 
DAGDELEN S., SENER D., BAYRAKTAR M. (2007). Influence of type 2 diabetes mellitus on bone mineral density response to bisphosphonates in late postmenopausal osteoporosis. Adv Ther. 24,1314-20.

DELL R., GREENE D., (2010). Is osteoporosis disease management cost effective? Curr Osteoporos Rep. 8, 49-55.

DELMAS PD., RIZZOLI R., COOPER C., REGINSTER JY. (2005). Treatment of patients with postmenopausal osteoporosis is worthwhile. The position of the International Osteoporosis Foundation. Osteoporos Int. 16, 1-5.

DELMAS PD., LI Z., COOPER C. (2004). Relationship between changes in bone mineral density and fracture risk reduction with antiresorptive drugs: some issues with meta-analyses. J Bone Miner Res. 19; 330-327.

DRIELING RL., MA J., THIYAGARAJAN S., STAFFORD RS. (2011). An Internetbased osteoporotic fracture risk program: effect on knowledge, attitudes, and behaviors. J Womens Health (Larchmt). 12, 1895-907.

FANG Y., RIVADENEIRA F., VAN MEURS JB., POLS HA., IOANNIDIS JP., UITTERLINDEN AG. (2006). Vitamin D receptor gene BsmI and TaqI polymorphisms and fracture risk: a meta-analysis. Bone. 39, 938-945.

FRANKEN AA., VAN BLIJDERVEEN NJ., WITJES MJ., NETELENBOS CJ. (2011). Bisphosphonate-related osteonecrosis of the jaw. Ned Tijdschr Geneeskd. 155, A3077.

FRANZO A., FRANCESCUTTI C., SIMON G. (2005). Risk factors correlated with post operative mortality for hip fracture surgery in the elderly: a population-based approach. Eur J Epidemiol. 20, 985-991.

GATES BJ., SONNETT TE., DUVALL CAK., DOBBINS EK. (2009). Review of osteoporosis pharmacotherapy for geriatric patients. Am J Geriatr Pharmacother. 7, 293-323.

GERVASINI G., BENÍTEZ J., CARRILLO JA. (2010). Pharmacogenetic testing and therapeutic drug monitoring are complementary tools for optimal individualization of drug therapy. Eur J Clin Pharmacol. 66, 755-74.

GONG L., ALTMAN RB., KLEIN TE. (2011). Bisphosphonates pathway. Pharmacogenet Genomics. 21, 50-3.

GURWITZ D. (2010). Pharmacogenetics education: 10 years of experience at Tel Aviv University. Pharmacogenomics. 11, 647-9.

HANEY E., BLIZIOTES M. (2008). Male Osteoporosis: New Insights in an Understudied Disease Curr Opin Rheumatol. 20, 423-428.

HARDING B., CURLEY AJ., HANNAN F., CHRISTIE PT., BOWL MR., TURNER JJ, et al. (2006). Functional characterization of calcium sensing receptor polymorphisms 
and absence of association with indices of calcium homeostasis and bone mineral density Clinical Endocrinology. 65, 598-605.

HEILBERG IP., HERNANDEZ E., ALONZO E., VALERA R., FERREIRA LG., GOMES SA., et al. (2005). Estrogen receptor (ER) gene polymorphism may predict the bone mineral density response to raloxifene in postmenopausal women on chronic hemodialysis. Ren Fail. 27, 155-61.

HOFBAUER LC., KHOSLA S., DUNSTAN CR., LACEY DL., BOYLE WJ., RIGGS BL. (2000). The roles of osteoprotegerin and osteoprotegerin ligand in the paracrine regulation of bone resorption. J. Bone Miner. 1, 2-12.

HSU Y., ZILLIKENS M., SCOTT G., FARBER CR., DEMISSIE S., SORANZO N., et al. (2010). An Integration of Genome-Wide Association Study and Gene Expression Profiling to Prioritize the Discovery of Novel Susceptibility Loci for OsteoporosisRelated Traits. PLoS Genet. 6, e1000977.

ICHIKAWA S., KOLLER D., PEACOCK M., JOHNSON ML., LAI D., HUI SL., et al. (2005). Polymorphisms in the estrogen receptor $\beta$ (ESR2) gene are associated with bone mineral density in Caucasian men and women. J. Clin.Endocrinol. Metab. 90, 59215927.

JI GR., YAO M., SUN CY., LI ZH., HAN Z. (2010). BsmI, TaqI, ApaI and FokI polymorphisms in the vitamin $\mathrm{D}$ receptor (VDR) gene and risk of fracture in Caucasians: A meta-analysis. Bone. 47:681-686.

JOHNELL O., KANIS JA. (2006). An estimate of the worldwide prevalence and disability associated with osteoporotic fractures. Osteoporos Int. 17, 1726-33.

Jones HD., Kong YY. Penninger JM. (2002). Role of RANKL and RANK in bone loss and arthritis. Ann. Rheum. Dis. 2, 32-39.

KAMEDA T., MANO H., YAMADA Y., TAKAI H., AMIZUKA N., KOBORI M., et al. (1998). Calcium-sensing receptor in mature osteoclasts, which are bone resorbing cells. Biochem Biophys Res Commun. 245: 419-422.

KANIS JA. (2002). Diagnosis of osteoporosis and assessment of fracture risk. Lancet. 359, 1929-1936.

KAPUR K., JOHNSON T., BECKMANN N., SEHMI J., TANAKA T., KUTALIK Z., et al. (2010). Genome-Wide Meta-Analysis for Serum Calcium Identifies Significantly Associated SNPs near the Calcium-Sensing Receptor (CASR) Gene. PLoS Genet 7, e1001035.

KARASIK D., CHEUNG CL., ZHOU Y., CUPPLES LA., KIEL DP., DEMISSIE S. (2012). Genome-wide association of an integrated osteoporosis-related phenotype: is there evidence for pleiotropic genes? J Bone Miner Res. 27, 319-330. 
KATZ J., GONG Y., SALMASINIA D., HOU W.,BURKLEY B., FERREIRA P., et al. (2011). Genetic polymorphisms and other risk factors associated with bisphosphonate induced osteonecrosis of the jaw. Int J Oral Maxillofac Surg. 40, 605-11.

KENNEL KA., DRAKE MT. (2009). Adverse effects of bisphosphonates: implications for osteoporosis management. Mayo Clin Proc. 84, 632-7.

KRUK M., RALSTON SH., ALBAGHA OM. (2009). LRP5 polymorphisms and response to risedronate treatment in osteoporotic men. Calcif Tissue Int. 84,171-9.

LAMBERTS S., UITTERLINDEN A. (2009). Genetic testing in clinical practice. Annu Rev Med. 60, 431-442.

LEHRER S., MONTAZEM A., RAMANATHAN L., PESSIN-MINSLEY M., PFAIL J., STOCK RG., et al. (2009). Bisphosphonate-induced osteonecrosis of the jaws, bone markers, and a hypothesized candidate gene. J Oral Maxillofac Surg. 1, 159-61.

LENISE A., CUMMINGS-VAUGHN., GAMMACK JK. (2010). Falls, osteoporosis and hip fractures. Med Clin N Am. 95, 495-506.

LESLIE WD., METGE CJ., AZIMAEE M., LIX LM., FINLAYSON GS., MORIN SN, et al. (2011). Direct costs of fractures in Canada and trends 1996-2006: A populationbased cost-of-illness analysis. J Bone Miner Res. 26, 2419-29.

LEVY ME., PARKER RA., FERRELL RE., ZMUDA JM., GREENSPAN SL. (2007). Farnesyl diphosphate synthase: a novel genotype association with bone mineral density in elderly women. Maturitas. 57, 247-52.

LEWIECKI EM. (2011). New targets for intervention in the treatment of postmenopausal osteoporosis. Nat Rev Rheumatol. 7, 631-8.

LEWIECKI EM. (2003). Nonresponders to osteoporosis therapy. J Clin Densitom. 6, 307-14.

MACDONALD H., MCGUIGAN F., STEWART A., BLACK AJ, FRASER WD., RALSTON S., et al. (2006). Large-scale population-based study showns no evidence of association between common polymorphism of the VDR gene and BMD in british women. J Bone Miner Res. 21, 151-162.

MACLAUGHLIN E. (2010). Improving osteoporosis screening, risk assessment, diagnosis, and treatment initiation: role of the health-system pharmacist in closing the gap. Am J Health Syst Pharm. 67, 4-8.

MAIZE DF., FULLER SH., HRITCKO PM, MATSUMOTO R., SOLTIS DA, TAHERI RR, et al. (2010). A review of remediation programs in pharmacy and other health professions. Am J Pharm Educ. 2, 25.

MANI A., RADHAKRISHNAN J., WANG H., MANI A., MANI MA., NELSONWILLIAMS C., et al. (2007). LRP6 mutation in a family with early coronary disease and metabolic risk factors. Science. 315, 1278-82. 
MANN V. RALSTON SH. (2003). Meta analysis of COL1A1 Sp1 polymorphism in relation to bone mineral density and osteoporotic fracture. Bone. 32, 711-717.

MARC J., PREZELJ J., KOMEL R., KOCIJANCIC A. (1999). VDR genotype and response to etidronate therapy in late postmenopausal women. Osteoporos Int. 10, 3036.

MARINI F., TONELLI P., CAVALLI L., CAVALLI T., MASI L., FALCHETTI A., et al. (2011). Pharmacogenetics of bisphosphonate-associated osteonecrosis of the jaw. Front Biosci (Elite Ed) 3, 364-70.

MARINI F., FALCHETTI A., SILVESTRI S., BAGGER Y., LUZI E., TANINI A., et al. (2008). Modulatory effect of farnesyl pyrophosphate synthase (FDPS) rs2297480 polymorphism on the response to long-term amino-bisphosphonate treatment in postmenopausal osteoporosis. Curr Med Res Opin. 24, 2609-15.

MENCEJ-BEDRAC S., PREZELJ J., KOCJAN T., KOMADINA R., MARC J. (2009). Analysis of association of LRP5, LRP6, SOST, DKK1, and CTNNB1 genes with bone mineral density in a Slovenian population. Calcif Tissue Int. 85,501-6.

MURPHY JE., GREEN JS., ADAMS LA., SQUIRE RB., KUO GM., MCKAY A. Pharmacogenomics in the curricula of colleges and schools of pharmacy in the United States. Am J Pharm Educ. 2010; 74(1):7.

NATIONAL INSTITUTE FOR HEALTH AND CLINICAL EXCELLENCE (NICE): Technology appraisal guidance 161 (amended January 2010): Alendronate, etidronate, risedronate, raloxifene and strontium ranelate for the primary prevention of osteoporotic fragility fractures in postmenopausal women. http://www.nice.org.uk/nicemedia/live/11748/47177/47177.pdf.

NATIONAL INSTITUTE FOR HEALTH AND CLINICAL EXCELLENCE (NICE): Technology appraisal guidance 160 (amended January 2010): Alendronate, etidronate, risedronate, raloxifene and strontium ranelate for the primary prevention of osteoporotic fragility fractures in postmenopausal women. http://www.nice.org.uk/nicemedia/pdf/TA160guidance.pdf.

NGUYEN ND., EISMAN JA., CENTER JR., NGUYEN TV. (2007). Risk factors for fracture in nonosteoporotic men and women. J Clin Endocrinol Metab. 92, 955-962.

NIH CONSENSUS DEVELOPMENT PANEL ON OSTEOPOROSIS PREVENTION, DIAGNOSIS, AND THERAPY. (2001). Osteoporosis prevention, diagnosis, and therapy. JAMA. 285, 785-795.

QURESHI AM., HERD RJ., BLAKE GM., FOGELMAN I., RALSTON SH. (2002). COLIA1 Sp1 polymorphism predicts response of femoral neck bone density to cyclical etidronate therapy. Calcif Tissue Int. 70, 158-63.

PALOMBA S., ORIO F JR., RUSSO T., FALBO A., TOLINO A., MANGUSO F., et al. (2005). BsmI vitamin D receptor genotypes influence the efficacy of antiresorptive 
treatments in postmenopausal osteoporotic women. A 1-year multicenter, randomized and controlled trial. Osteoporos Int. 16:943-52.

PALOMBA S., NUMIS FG., MOSSETTI G., RENDINA D., VUOTTO P., RUSSO T., et al. (2003). Raloxifene administration in postmenopausal women with osteoporosis: effect of different BsmI vitamin D receptor genotypes. Hum Reprod. 18, 192-8.

PATSCH JM., DEUTSCHMANN J., PIETSCHMANN P. (2011). Gender aspects of osteoporosis and bone strength. Wien Med Wochenschr. 161, 117-23.

PEARCE SH. THAKKER RV. (1997). The calcium-sensing receptor: insights into extracellular calcium homeostasis in health and disease. J Endocrinol. 154, 371-378.

PIETSCHMANN P., RAUNER M., SIPOS W., KERSCHAN-SCHINDL K. (2009). Osteoporosis: An Age-Related and Gender-Specific Disease - A Mini-Review. Gerontology. 55, 3-12.

PIKE C., BIRNBAUM HG., SCHILLER M., SHARMA H., BURGE R., EDGELL ET. (2010). Direct and indirect costs of non-vertebral fracture patients with osteoporosis in the US. Pharmacoeconomics. 28, 395-409.

RACHNER TD., KHOSLA S., HOFBAUER LC. (2011). Osteoporosis: now and the future. Lancet 377, 1276-87.

RALSTON SH. (2010). Genetics of osteoporosis. Ann N Y Acad Sci. 1192,181-9

RALSTON SH. (2010). Uitterlinden AG. Genetics of osteoporosis. Endocr Rev. 31, 629-62.

RALSTON SH. (2002). Genetic control of susceptibility to osteoporosis. J Clin Endocrinol Metab. 87, 2460-2466.

REID IR. (2009). Osteonecrosis of the jaw: who gets it, and why? Bone. 44:4-10.

REPPE S., REFVEM H., GAUTVIK VT., OLSTAD OK., HØVRING PI., REINHOLT FP., et al. (2010). Eight genes are highly associated with BMD variation in postmenopausal Caucasian women. Bone. 46:604-12.

RICHARDS JB., KAVVOURA FK., RIVADENEIRA F., STYRKÁRSDÓTTIR U., ESTRADA K., HALLDÓRSSON BV., et al. (2009). Collaborative meta-analysis: associations of 150 candidate genes with osteoporosis and osteoporotic fracture. Ann Intern Med. 151, 528-37.

RIVADENEIRA F., STYRKÁRSDOTTIR U., ESTRADA K., HALLDÓRSSON B., HSU Y., RICHARDS J., et al. (2009). Twenty bone-mineral-density loci identified by large-scale meta-analysis of genome-wide association studies. Nat Genet. 41:1199-206.

ROJO K., AZNARTE P., CALLEJA MA., CONTRERAS C., MARTÍNEZ JL., LÓPEZ-MEZQUITA B., et al. (2010). Factors of risk in an elderly population: evaluation for the prevention of hip fractures. Rev Cir Ortp Traumatol. 54, 167-173. 
RIZZOLI R, REGINSTER JY, BOONEN S, BRÉART G, DIEZ-PEREZ A, FELSENBERG D, et al. (2011). Adverse reactions and drug-drug interactions in the management of women with postmenopausal osteoporosis. Calcif Tissue Int. 89, 91104.

SARASQUETE ME., GONZÁLEZ M., SAN MIGUEL JF., GARCÍA-SANZ R. (2009) Bisphosphonate-related osteonecrosis: genetic and acquired risk factors. Oral Diseases. $15,382-387$.

SARASQUETE ME., GARCÍA-SANZ R., MARÍN L., ALCOCEBA M, CHILLÓN MC, BALANZATEGUI A., et al. (2008). Bisphosphonate-related osteonecrosis of the jaw is associated with polymorphisms of the cytochrome P450 CYP2C8 in multiple myeloma: a genome-wide single nucleotide polymorphism analysis. Blood. 112, 270912.

SHAPSES SA., KENDLER D., ROBSON R., HANSEN KE., SHERRELL RM., FIELD MP., et al. (2001). Effect of alendronate and vitamin D(3) on fractional calcium absorption in a double-blind, randomized, placebo-controlled trial in postmenopausal osteoporotic women. J Bone Miner Res. 26, 1836-44.

SIMSEK M. CETIN Z. BILGEN T, TASKIN O, LULECI G, KESER I. (2008). Effects of hormone replacement therapy on bone mineral density in Turkish patients with or without COL1A1 Sp1 binding site polymorphism. J Obstet Gynaecol Res. 34, 73-7.

SIRIS ES., SELBY PL., SAAG KG., BORGSTRÖM F., HERINGS RM., SILVERMAN SL. (2009). Impact of osteoporosis treatment adherence on fracture rates in North America and Europe. Am J Med. 122, S3-13.

STYRKARSDOTTIR U., HALLDORSSON BV., GRETARSDOTTIR S., GUDBJARTSSON DF., WALTERS GB., INGVARSSON T., et al. (2009). New sequence variants associated with bone mineral density. Nat Genet. 41, 15-7.

TAMAI K., SEMENOV M., KATO Y., SPOKONY R., LIU C., KATSUYAMA Y., et al. (2000). LDL-receptor-related proteins in Wnt signal transduction. Nature. 407, 530535 .

TESCH G., AMUR S., SCHOUSBOE JT., SIEGEL JN., LESKO LJ., BAI JP. (2010). Successes achieved and challenges ahead in translating biomarkers into clinical applications. AAPS J. 12:243-53.

THE ECONOMIC COST OF HIP FRACTURE IN THE UK. (2000).Centre for Health Economics, University of York.

Trost Z., Trebse R., Prezelj J., Komadina R., Logar DB., Marc J. (2010).A microarray based identification of osteoporosis-related genes in primary culture of human osteoblasts. Bone. 46, 72-80.

TSUKAMOTO K. ORIMO H. HOSOI T., MIYAO M, OTA N, NAKAJIMA T, et al. (2000). Association of Bone Mineral Density with Polymorphism of the Human Calcium-Sensing Receptor Locus. Calcif Tissue Intern. 66:181-183 
UITTERLINDEN AG., RALSTON SH., BRANDI ML., CAREY AH., GRINBERG D., LANGDAHL BL., et al. (2006). The association between common vitamin D receptor gene variations and osteoporosis: a participant-level meta-analysis. Ann Intern Med. 145, 255-264.

U.S. FOOD AND DRUG ADMINISTRATION, European Commission, European Medicines Agency. General principles Processing Joint FDA EMEA Voluntary Genomic Data Submissions (VGDSs) within the framework of the Confidentiality Arrangement.

http://www.ema.europa.eu/docs/en_GB/document_library/Scientific_guideline/2009/09/ WC500003887.pdf

VAN STRAATEN T., VAN SCHAIK R. (2010). Genetic techniques for pharmacogenetic analyses. Curr Pharm Des. 16, 231-237.

WANG C., HE JW., QIN YJ., ZHANG H., HU WW., LIU YJ., et al. (2009). Osteoprotegerin gene polymorphism and therapeutic response to alendronate in postmenopausal women with osteoporosis. Zhonghua Yi Xue Za Zhi. 89, 2958-62.

Weinshilboum R. (2003). Inheritance and drug response. N Engl J Med. 348, 529-537.

WESLEY P., HIRONORI Y., NIRUPAMA K. (2002). Vitamin D receptor-mediated gene regulation mechanisms and current concepts of vitamin D analog selectivity. Adv. Ren. Replace. Ther. 3, 168-174.

YAZDANPANAH N. RIVADENEIRA F. VAN MEURS JB, ZILLIKENS MC, ARP P, HOFMAN A, et al. (2007). The $-1997 \mathrm{G} / \mathrm{T}$ and Sp1 polymorphisms in the collagen type I a1 (COLIA1) gene in relation to changes in femoral neck bone mineral density and the risk of fracture in the elderly: the Rotterdam study. Calcif Tissue Int. 1, 18-25.

ZEBAZE RM., GHASEM-ZADEH A., BOHTE A., IULIANO-BURNS S., MIRAMS M., PRICE RI., et al. (2010). Intracortical remodelling and porosity in the distal radius and post-mortem femurs of women: a cross-sectional study. Lancet. 375, 1729-36.

ZHANG LS., HU HG., LIU YJ., Li J., Yu P., Zhang F., et al. (2011). A follow-up association study of two genetic variants for bone mineral density variation in Caucasians. Osteoporos Int. 7, 1867-75.

ZHENG HF., SPECTOR TD., RICHARDS JB. (2011). Insights into the genetics of osteoporosis from recent genome-wide association studies. Expert Rev Mol Med. 13, e28. 
Table 1: Updated signalling pathways and putative genes involved in osteoporosis and osteoporotic fractures.

\begin{tabular}{|c|c|c|c|}
\hline Name of Pathways & $\begin{array}{c}\text { Name Genes } \\
\text { (Alternative symbols) }\end{array}$ & $\begin{array}{l}\text { Genetic and } \\
\text { genomic screening } \\
\text { technologies/ } \\
\text { approaches }\end{array}$ & References \\
\hline Osteoclastogenesis & $\begin{array}{l}\text { Osteoprotegerine (OPG), } \\
\text { Receptor activator of } \mathrm{NF}_{-\mathrm{k}} \mathrm{B} \\
\text { Ligand (RANK-L), Receptor } \\
\text { activator of NF-kB (RANK). }\end{array}$ & $\begin{array}{l}\text { GWAS } \\
\text { Candidate gene } \\
\text { Meta-analysis }\end{array}$ & $\begin{array}{l}\text { Hsu Yi- } \\
\text { Hsiang, } \\
\text { 2010; } \\
\text { Richards JB., } \\
\text { 2009; } \\
\text { Rivadeneira } \\
\text { F.,2009; } \\
\text { Styrkarsdottir } \\
\text { U., 2009; } \\
\text { Ralston SH., } \\
\text { 2010, } \\
\text { 31:629-62; } \\
\text { Ralston SH., } \\
\text { 2010; } \\
\text { 1192:181-9; }\end{array}$ \\
\hline $\begin{array}{l}\text { Wingless-type } \\
\text { MMTV intregration } \\
\text { site (Wnt) signalling }\end{array}$ & $\begin{array}{l}\text { Low density lipoprotein } \\
\text { receptor-related protein } 5 \\
\text { and } 6 \text { (LRP4, LRP-5, LRP-6), } \\
\text { Integrin- } \beta \text { (ITGB), Integrin- } \alpha \text {, } \\
\text { Dickkopf-1 } \\
\text { Sclerostin (SOST), secreted } \\
\text { frizzled-related protein (Sfrp). }\end{array}$ & $\begin{array}{l}\text { GWAS } \\
\text { Candidate gene } \\
\text { Meta-analysis }\end{array}$ & $\begin{array}{l}\text { Richards JB., } \\
\text { 2009; } \\
\text { Rivadeneira } \\
\text { F.,2009; } \\
\text { Styrkarsdottir } \\
\text { U., 2009; } \\
\text { Ralston SH., } \\
\text { 2010, } \\
31: 629-62 ; \\
\text { Ralston SH., } \\
\text { 2010, } \\
\text { 1192:181-9; } \\
\text { Mencej- } \\
\text { Bedrac S., } \\
\text { 2009; Reppe } \\
\text { S., 2010; }\end{array}$ \\
\hline $\begin{array}{l}\text { Other Main } \\
\text { Signalling } \\
\text { Proliferation/Inhibiti } \\
\text { on Growth Cellular: }\end{array}$ & $\begin{array}{l}\text { secreted phosphoprotein } 1 \\
\text { (SPP1), spectrin beta non- } \\
\text { erythrocytic } 1 \text { (SPTBN1), G } \\
\text { protein-coupled receptor } 177\end{array}$ & $\begin{array}{l}\text { GWAS } \\
\text { Candidate gene } \\
\text { Meta-analysis }\end{array}$ & $\begin{array}{l}\text { Hsu Yi- } \\
\text { Hsiang., } \\
\text { 2010; } \\
\text { Richards JB., } \\
\text { 2009; } \\
\text { Rivadeneira } \\
\text { F., 2009; }\end{array}$ \\
\hline
\end{tabular}




\begin{tabular}{|c|c|c|c|}
\hline $\begin{array}{l}\text { - Canonical Wnt } \\
\text { - TGF-B signalling } \\
\text {-Beta-catenin } \\
\text { phosphorilation } \\
\text { - MAPK pathway }\end{array}$ & $\begin{array}{l}\text { (GPR177), catenin (cadherin- } \\
\text { associated protein) beta } 1 \\
\text { (CTNNB1), myocyte } \\
\text { enhancer factor 2C } \\
\text { (MEF2C), SRY (sex } \\
\text { determining region Y)-box } 6 \\
\text { (SOX6), histone deacetylase } \\
5 \quad \text { (HDAC5), corticotropin } \\
\text { releasing hormone receptor } 1 \\
\text { (CRHR1), zinc finger and } \\
\text { BTB domain-containing } \\
\text { protein } 40 \quad \text { (ZBTB40), } \\
\text { Forkhead box protein L1 } \\
\text { (FOXL1), Osterix (OS7). }\end{array}$ & & $\begin{array}{l}\text { Ralston SH., } \\
\text { 2010, } \\
\text { 31:629-62.; } \\
\text { Ralston SH., } \\
\text { 2010, } \\
\text { 1192:181-9; } \\
\text { Mencej- } \\
\text { Bedrac S., } \\
\text { 2009; } \\
\text { Uitterlinden } \\
\text { AG., 2006; }\end{array}$ \\
\hline Vitamin D & $\begin{array}{l}\text { Vitamin D receptor (VDR), } \\
\text { Vitamin D receptor binding } \\
\text { protein (DBP). }\end{array}$ & $\begin{array}{l}\text { GWAS } \\
\text { Candidate gene } \\
\text { Meta-analysis }\end{array}$ & $\begin{array}{l}\text { Ralston SH., } \\
\text { 2010, } \\
\text { 31:629-62; } \\
\text { Ralston SH., } \\
\text { 2010, } \\
\text { 1192:181-9; } \\
\text { Uitterlinden } \\
\text { AG., 2006; Ji } \\
\text { GR., 2010; } \\
\text { Fang Y., } \\
\text { 2006; } \\
\text { Macdonald } \\
\text { H., 2006; }\end{array}$ \\
\hline Estrogens & $\begin{array}{l}\text { Estrogen receptor- } \alpha(E S R-\alpha) \text {, } \\
\text { Estrogen receptor- } \beta \text { (ESR- } \\
\beta) .\end{array}$ & $\begin{array}{l}\text { GWAS } \\
\text { Candidate gene }\end{array}$ & $\begin{array}{l}\text { Richards JB., } \\
2009 \text {; } \\
\text { Ralston SH., } \\
2010 \text {, } \\
31: 629-62 ; \\
\text { Ralston SH., } \\
2010 \text {, } \\
\text { 1192:181-9; }\end{array}$ \\
\hline Collagen & Collagen type $1 \mathrm{~A}$ (COL1A1) & $\begin{array}{l}\text { GWAS } \\
\text { Candidate gene } \\
\text { Meta-analysis }\end{array}$ & $\begin{array}{l}\text { Ralston SH., } \\
2010, \\
\text { 31:629-62; } \\
\text { Ralston SH., }\end{array}$ \\
\hline
\end{tabular}




\begin{tabular}{|c|c|c|c|}
\hline & & & $\begin{array}{l}\text { 2010, } \\
\text { 1192:181-9; } \\
\text { Mann V., } \\
\text { 2003; } \\
\text { Yazdanpana } \\
\text { h N., 2007; }\end{array}$ \\
\hline $\begin{array}{l}\text { Homeostasis } \\
\text { calcium } \\
\text { phosphorus }\end{array}$ & $\begin{array}{l}\text { Calcium sensing Receptor } \\
\text { (CaSR) }\end{array}$ & $\begin{array}{l}\text { GWAS } \\
\text { Candidate gene } \\
\text { Metaanalysis }\end{array}$ & $\begin{array}{l}\text { Hsu } \\
\text { Hsiang, } \\
\text { 2010; Kapur } \\
\text { K., Año; } \\
\text { Tsukamoto } \\
\text { K., 2000; } \\
\text { Harding B., } \\
\text { 2006; }\end{array}$ \\
\hline Mevalonate & $\begin{array}{l}\text { Farnesyl diphosphate } \\
\text { synthase } \\
\text { geranylgeranyl diphosphate } \\
\text { synthase 1 (GGPS1) }\end{array}$ & $\begin{array}{l}\text { GWAS } \\
\text { Candidate gene }\end{array}$ & $\begin{array}{lr}\text { Marini } & \text { F., } \\
2008 ; & \text { Choi } \\
\text { HJ., } & 2010 ; \\
\text { Levy } & \text { ME. } \\
2007 & \end{array}$ \\
\hline
\end{tabular}


Table 2: Summary of relevant pharmacogenetic studies on antirresorptive drug response

\begin{tabular}{|c|c|c|c|c|c|}
\hline Gene & Variant (alleles) & Osteoporotic Drug & Phenotype & Drug Efficacy & Reference \\
\hline \multirow[t]{4}{*}{ VDR } & rs1544410-Bsml (G>A) & Raloxifene & BMD & $\begin{array}{l}\text { The increase in lumbar BMD was higher in patients } \\
\text { homozygous GG compared to those with the heterozygous } \\
\text { genotype. }\end{array}$ & $\begin{array}{l}\text { Palomba, et al. } \\
2003\end{array}$ \\
\hline & & Etidronate & BMD & $\begin{array}{l}\text { The increase in lumbar BMD was higher in patents homozygous } \\
\text { GG compared to those with the heterozygous genotype. }\end{array}$ & Marc J. et al 2009 \\
\hline & & $\begin{array}{l}\text { Alendronate + HRT } \\
\text { Alendronate + Raloxifene } \\
\text { Alendronate alone }\end{array}$ & BMD & $\begin{array}{l}\text { The increase in lumbar BMD was higher in patients } \\
\text { heterozygous } A G \text { and homozygous } G G \text {. }\end{array}$ & $\begin{array}{l}\text { Palomba, et al. } \\
2003\end{array}$ \\
\hline & & $\begin{array}{l}\text { Alendronate or } \\
\text { Teriparatide }\end{array}$ & BMD & $\begin{array}{l}\text { Effectiveness in BMD only with alendronate treatment. Carriers } \\
\text { patients of the } A \text { allele }(A G, A A) \text { presented more responsive to } \\
\text { treatment compared to patients with the GG genotype Bsml } \\
\text { polymorphism. }\end{array}$ & \\
\hline \multirow[t]{2}{*}{ ER } & $\begin{array}{l}\text { rs2234693-Pvull }(T>C) \\
\text { rs9340799-Xbal }(C>G)\end{array}$ & Raloxifene & BMD & $\begin{array}{l}\text { The increase in lumbar BMD was higher in patients } \\
\text { homozygous PP (TT) for the Pvull polymorphism and patients } \\
\text { homozygous xx (GG) for the Xbal polymorphism. }\end{array}$ & $\begin{array}{l}\text { Heilberg IP. et al } \\
2005 .\end{array}$ \\
\hline & rs1256049-Rsal $(A>G)$ & Alendronate & BMD & $\begin{array}{l}\text { A smaller increase on lumbar BMD, but no significant different, } \\
\text { was showed in patients with heterozygous GA. }\end{array}$ & Arko B. et al 2002 \\
\hline \multirow[t]{2}{*}{ COL1A1 } & rs1800012-Sp1 (G>T) & Etidronate & BMD & $\begin{array}{l}\text { The increase in femoral neck BMD was higher in patients } \\
\text { homozygous GG (SS) in comparison with the rest of the } \\
\text { genotype }\end{array}$ & $\begin{array}{l}\text { Qureshi AM, et al. } \\
2002\end{array}$ \\
\hline & & $\begin{array}{l}\text { Hormone replacement } \\
\text { therapy (HRT) }\end{array}$ & BMD & $\begin{array}{l}\text { The increase in lumbar BMD and femoral BMD were higher in } \\
\text { patients homozygous GG compared to those with heterozygous } \\
\text { genotype. }\end{array}$ & $\begin{array}{l}\text { Simsek M, et al. } \\
2008\end{array}$ \\
\hline \multirow[t]{2}{*}{ FDPS } & rs2297480 (A>C) & $\begin{array}{l}\text { Alendronate or } \\
\text { ibandronate }\end{array}$ & BMD & Any relationship was found with spinal and femoral BMD. & $\begin{array}{l}\text { Marini F., et al } \\
2008\end{array}$ \\
\hline & $\begin{array}{l}\mathrm{rs} 2297480(\mathrm{~A}>\mathrm{C}) \\
\mathrm{rs} 11264361(\mathrm{G}>\mathrm{T})\end{array}$ & $\begin{array}{l}\text { Alendronate or } \\
\text { Risedronate }\end{array}$ & BMD & $\begin{array}{l}\text { Any polymorphisms were associated with lumbar spine BMD or } \\
\text { femoral neck BMD. }\end{array}$ & $\begin{array}{l}\text { Choi HJ., et al } \\
2010\end{array}$ \\
\hline LRP5 & $\begin{array}{l}\text { rs3736228 (C>T) } \\
\text { rs4988321 (G>A/C) }\end{array}$ & Risedronate & BMD & Any relationship was found with BMD at any site. & $\begin{array}{l}\text { Kruk M., et al. } \\
2009\end{array}$ \\
\hline OPG & $\begin{array}{l}\mathrm{rs} 3102735(A>G) \\
\mathrm{rs} 3134069(T>G)\end{array}$ & Alendronate & BMD & $\begin{array}{l}\text { At site A163G, the increase in femoral neck BMD was higher in } \\
\text { patients homozygous AA, while at site T245G, the percentage } \\
\text { of BMD change at inter-troche and total hip were higher in } \\
\text { genotype TT. }\end{array}$ & $\begin{array}{l}\text { Wang C., et al. } \\
2009\end{array}$ \\
\hline GGPS1 & rs3840452 (8188T ins / & Alendronate or & BMD & Patients with two deleted allele of GGPS1 $-8188 \mathrm{~A}$ ins/del was & Choi HJ., et al. \\
\hline
\end{tabular}




\begin{tabular}{|l|l|l|l|}
\hline del) & Risedronate & $\begin{array}{l}\text { significantly lower than the rate of patients with one or no } \\
\text { deleted allele. Patients with two deleted allele had 7-fold higher } \\
\text { risk of non-response to bisphosphonate therapy compared with } \\
\text { women with other genotypes in GGPS1 -8188, after adjusting } \\
\text { for baseline BMD. }\end{array}$ \\
\hline
\end{tabular}

BMD: bone mineral density. HRT: Hormone replacement therapy. Ref.: reference. 
Table 3: Side-effect of established treatments for osteoporosis.

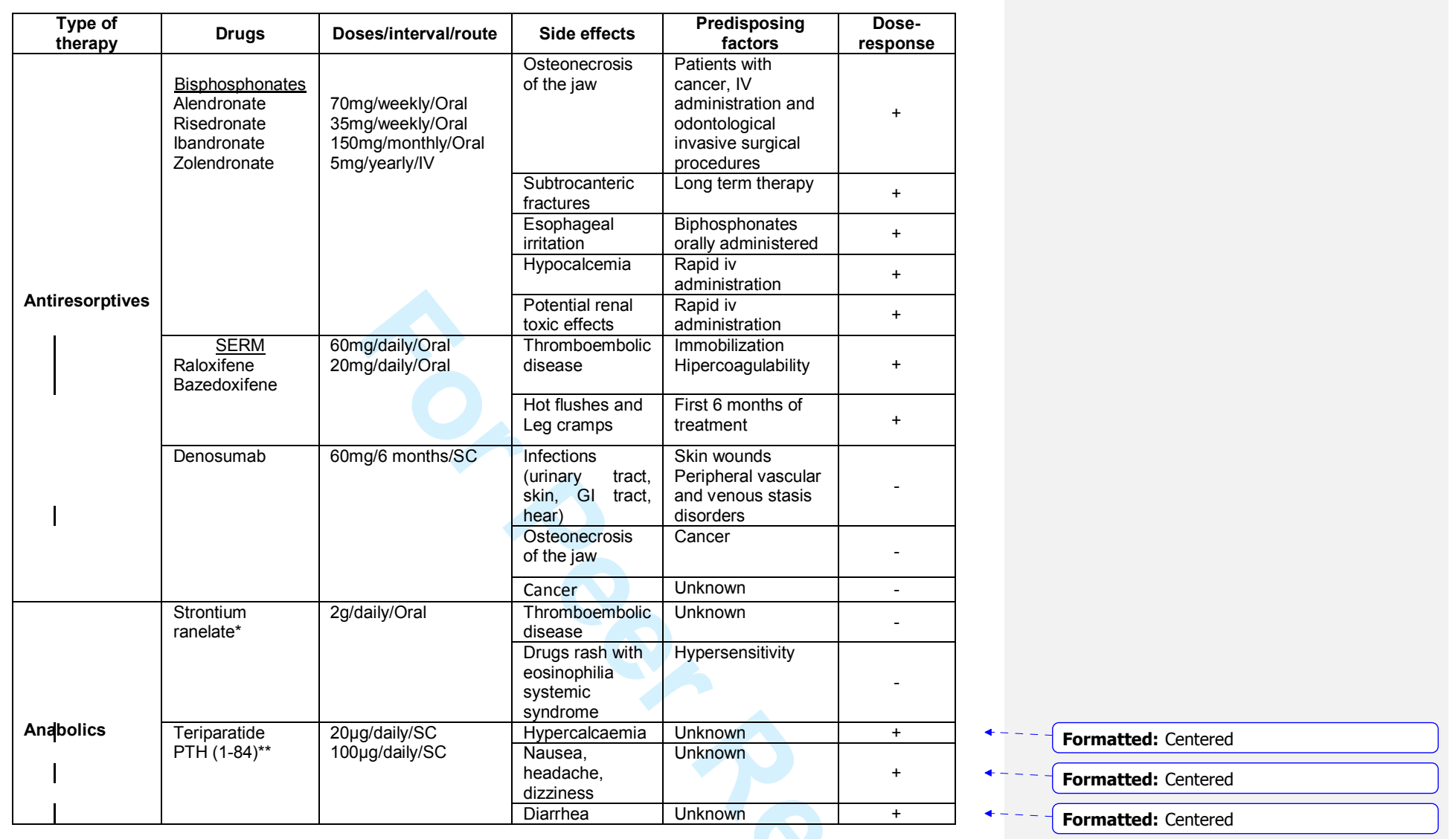

IV: Intravenenous. SC: Subcutaneous. * Approved in more 70 countries. ${ }^{*}$ Approved in European but no in USA. 
Table 4: Summary of pharmacogenetic studies of adverse events with bisphosphonates.

\begin{tabular}{|c|c|c|c|c|c|}
\hline Gene & Variant & Osteoporotic Drug & $\begin{array}{l}\text { Adverse drug } \\
\text { reactions }\end{array}$ & Results & Ref. \\
\hline CYP2C8 & rs1934951 (C>T) & $\begin{array}{l}\text { Bisphosphonates } \\
\text { (pamidronate or } \\
\text { zaledronate) }\end{array}$ & ONJ & $\begin{array}{l}\text { Homozygosity for the T allele was associated with increased } \\
\text { risk of developing ONJ. }\end{array}$ & $\begin{array}{l}\text { Sarasquete ME., } \\
\text { et al 2008, } \\
\text { Sarasquete ME., } \\
\text { et al } 2009 .\end{array}$ \\
\hline MMP2 & No defined & $\begin{array}{l}\text { Bisphosphonates } \\
\text { (pamidronate or } \\
\text { zaledronate or } \\
\text { alendronate }\end{array}$ & ONJ & $\begin{array}{l}\text { This protein was selected on the basis of its potential } \\
\text { involvement in the breakdown of extracellular matrix in } \\
\text { normal physiological processes, such as tissue remodelling, } \\
\text { as well as in disease processes, such as arthritis and } \\
\text { metastasis. }\end{array}$ & $\begin{array}{l}\text { Lehrer S., et al } \\
2009\end{array}$ \\
\hline RANK & rs12458117 (A>G) & $\begin{array}{l}\text { Bisphosphonates } \\
\text { (pamidronate or } \\
\text { zaledronate) }\end{array}$ & ONJ & $\begin{array}{l}\text { A trend towards higher odds ratio for developing ONJ in } \\
\text { patients with multiple myeloma undergoing intravenous BP } \\
\text { therapy was observed for the combined genotype score } \\
\text { together with other gene SNPS (COL1A1, MMP2, OPG, OPN) }\end{array}$ & $\begin{array}{l}\text { Katz J., et al } \\
2011 .\end{array}$ \\
\hline MMP2 & rs243865 (C>T) & $\begin{array}{l}\text { Bisphosphonates } \\
\text { (pamidronate or } \\
\text { zaledronate) }\end{array}$ & ONJ & $\begin{array}{l}\text { A trend towards higher odds ratio for developing ONJ in } \\
\text { patients with multiple myeloma undergoing intravenous BP } \\
\text { therapy was observed for the combined genotype score } \\
\text { together with other gene SNPS (COL1A1, RANK, OPG, } \\
\text { OPN,) }\end{array}$ & $\begin{array}{l}\text { Katz J., et al } \\
2011 .\end{array}$ \\
\hline OPN & rs11730582 (C>T) & $\begin{array}{l}\text { Bisphosphonates } \\
\text { (pamidronate or } \\
\text { zaledronate) }\end{array}$ & ONJ & $\begin{array}{l}\text { A trend towards higher odds ratio for developing ONJ in } \\
\text { patients with multiple myeloma undergoing intravenous BP } \\
\text { therapy was observed for the combined genotype score } \\
\text { together with other gene SNPs (COL1A1, RANK, MMP2, } \\
\text { OPG) }\end{array}$ & $\begin{array}{l}\text { Katz J., et al } \\
2011 .\end{array}$ \\
\hline FDPS & rs2297480 (A>C) & zoledronic acid & ONJ & Positive correlation between AA carriers status and disease & Marini F., et al. \\
\hline
\end{tabular}




\section{Page 41 of 41}

OMICS: A Journal of Integrative Biology

1
2
3
4
5
6
7
8
9
10
11
12
13
14
15
16
17
18
19
20
21
22
23
24
25
26
27
28
29
30
31
31
32
33
34
35
36
37
38
39
40
45
43
45

\begin{tabular}{l|l|l|l|}
\hline & & $\begin{array}{l}\text { expression, as well as between CC carrier's status and the } \\
\text { absence of the ONJ complications. }\end{array}$ & 2011 \\
\hline
\end{tabular}

ONJ: osteonecrosis of the jaw. 